\title{
Histochemical Studies on the Conduction System of Diabetic Rat Hearts
}

\author{
Atsushi Kuroda ${ }^{1}$, Kazuto SaIto ${ }^{2}$ and Hiromitsu Tanaka ${ }^{1}$ \\ The First Department of Internal Medicine ${ }^{1}$, Kagoshima University School of Medicine, Kagoshima; and The Health Service \\ Center ${ }^{2}$, the National Institute of Fitness and Sports, Kanoya, Japan
}

Received October 5, 1989

\begin{abstract}
Summary. We studied the metabolism of the conduction system and the working myocardium in diabetic rat hearts by enzyme histochemistry. The experiment was performed three weeks following the administration of streptozotocin $(65 \mathrm{mg} / \mathrm{kg})$ to male Wistar rats. The hearts were quickly excised and tissue was frozen immediately by immersion in isopentane at $-30^{\circ} \mathrm{C}$ and cut into $16 \mu \mathrm{m}$ thick sections in a cryostat. The PAS positive reaction was increased in the conduction system compared to the working myocardium in control rats. In diabetic rat hearts, these reactions in the working myocardium and the conduction system were strongly increased compared to control hearts. Several enzyme activities, such as phosphofructokinase, pyruvate dehydrogenase, glucose-6-phosphate dehydrogenase, Na-K ATPase, were reduced in both the working myocardium and conduction system of diabetic rat hearts. These results suggest that the changes in metabolic condition also exist in the conduction system of the diabetic rat hearts as well as the working myocardium.
\end{abstract}

Diabetic hearts are known to have an altered myocardial metabolism, both in man and experimental animals (MCDANIEL et al., 1988). Myocardial metabolism in the poorly controlled diabetic animal is characterized by the exclusive oxidation of fatty acids and ketone bodies, and a low rate of glucose utilization (TAEgTMEYER and PASSMORE, 1985). The conduction system has been reported to have different metabolic properties compared to the working myocardium in normal hearts (SoGABE et al., 1987). It is well known that not only myocardial contractility but also the heart rate is reduced in diabetic animals. Alterations in the working myocardial metabolism have been extensively investigated by biochemical and enzyme histochemical methods in diabetic animals (TARACH, 1978), however, there has been no systematic study of the myocardial metabo- lism of the conduction system in diabetic animals. The present study was therefore undertaken to investigate alterations in the energy metabolism of the conduction system in diabetic rats. The cardiac conduction system is not easily isolated by dissection, and it is difficult to obtain a sufficient amount of material for accurate biochemical studies. For this reason, we used enzyme histochemistry and studied the activities of some enzymes related to glucose metabolism in diabetic rat hearts.

\section{MATERIALS AND METHODS}

\section{Animals and tissue preparation}

Male Wistar rats weighing approximately $150 \mathrm{~g}$ were randomly separated into control and diabetic groups. Diabetic groups received an intravenous injection of $0.1 \mathrm{M}$ citrate-buffered streptozotocin (Sigma Chemical Co.) at a dosage of $65 \mathrm{mg} / \mathrm{kg}$ body weight (GANDA et al., 1976). Control animals received a similar injection of citrate-buffer alone. These animals were kept for three weeks under normal laboratory conditions with access to water and rat chow ad libitum and then killed by decapitation at AM 9:00-11:00 after overnight fasting. Post-fasting blood glucose levels were measured by the glucose oxidase method, and a blood sugar level of above $300 \mathrm{mg} / \mathrm{dl}$ was taken as the criterion of diabetes. The hearts, including the proximal portion of the major vessels, were immediately removed and the area containing the atrioventricular node was dissected as follows: a horizontal cut was made to separate the atria and the proximal end of both ventricules from the rest of the heart. The distal portion of the heart, including the right ventricule and the left ventricule, was frozen by 
immersion in isopentane at $-30^{\circ} \mathrm{C}$. In a culture dish containing $3 \mathrm{mM}$ HEPES buffer, the appendage of the right atrium was removed, and the wall of the right ventricle was cut open to expose the area containing the coronary sinus, the tricuspid valve, and a portion of the interauricular and upper interventricular septa. The area containing the atrioventricular node, located between the coronary sinus and the aorta, was removed and frozen by immersion in isopentane at $-30^{\circ} \mathrm{C}$, and stored not longer than one week at $-70^{\circ} \mathrm{C}$. Frozen, $16 \mu \mathrm{m}$-thick sections were cut in a cryostat at $-20^{\circ} \mathrm{C}$. Sections containing the atrioventricular node were identified by staining alternate sections with 65 $\mathrm{mM}$ sodium hydrogen maleate buffer containing 2 $\mathrm{mM}$ acetylthiocholine iodide, $5 \mathrm{mM}$ sodium citrate, 3 $\mathrm{mM}$ copper sulfate, and $0.5 \mathrm{mM}$ potassium ferricyanide to detect acetylcholinesterase activity (KARNOVSKY, 1964). Alternate, unstained sections containing the atrioventricular node were thaw-mounted onto gelatin coated glass slides placed in a vacuum at $4^{\circ} \mathrm{C}$ and stored no longer than $24 \mathrm{~h}$ until incubation.

\section{Histochemistry}

For metabolic studies, these sections were stained by the following histochemical tecniques. Glycogen was demonstrated by the periodic acid-Schiff (PAS) technique (PEARSE, 1968). Oil red O was used to demonstrate lipid (PEARSE, 1968). The activity of glycogen phosphorylase (EC. 2. 4.1.1) was demonstrated by the method of TAKEUCHI (TAKEUCHI, 1955; TAKEUCHI and KURIAKI, 1962). The sections were incubated in a medium containing $100 \mathrm{mg}$ glucose-1-phosphate (Sigma Chem. Co.), 20 mg 5'-AMP (Sigma Chem. Co.),
$2 \mathrm{mg}$ glycogen, $5 \mathrm{mg}$ sodium fluoride, and $0.2 \mathrm{M}$ acetate buffer $(\mathrm{pH} 5.7,10 \mathrm{ml})$. The activity of phosphofructokinase (EC. 2. 7. 1. 11) was demonstrated by the method of Bonilla and SchuTLAND (1970). The sections were incubated in a medium containing 10 mM Fructose-6-phosphate (Sigma Chem. Co.), $10 \mathrm{mM}$ NAD (Kohjin Co.), 10 mM ATP (Sigma Chem. Co.), 40 $\mathrm{mM} \mathrm{MgSO} 4,20 \mathrm{mM}$ sodium arsenate $(\mathrm{pH} 7.0)$, and 10 $\mathrm{mg}$ nitro BT. The activity of glucose-6-phosphate dehydrogenase (EC. 2. 1. 1. 49) was demonstrated by the method of RUDOLPH and KLEIN (1964). The sections were incubated in a medium containing $4 \mathrm{mg}$ glucose-6-phosphate (sodium salt, Sigma Chem. Co.), $5 \mathrm{mg}$ NADP (Kohjin Co.), $2 \mathrm{mg}$ nitro BT, and $0.05 \mathrm{M}$ Tris buffer $(\mathrm{pH} 7.4,4 \mathrm{ml})$. The activity of pyruvate dehydrogenase (EC. 1. 2. 4. 1) was demonstrated by the method of FERGUSON (1966). The sections were incubated in a medium containing $2 \mathrm{mg}$ potasium pyruvate (Nakarai Chem. Co.), $0.5 \mathrm{mg}$ Co enzyme A (Kohjin Co.), $1 \mathrm{mg}$ NAD (Kohjin Co.), nitro BT, and $0.1 \mathrm{M}$ phosphate buffer $(\mathrm{pH} 7.4,4 \mathrm{ml})$. The activity of succinate dehydrogenase (EC. 1. 3. 99.1) was demonstrated by the method of NACHLAS et al. (1957). The sections were incubated in a medium containing 0.2 $\mathrm{M}$ sodium succinate, $0.2 \mathrm{M}$ phosphate buffer ( $\mathrm{pH} 7.6$ ), and $10 \mathrm{mg}$ nitro BT. The ouabain-sensitive $\mathrm{K}^{+}$-dependent p-nitrophenylphosphate $\left(\mathrm{K}^{+}\right.$-NPPase) of the $\mathrm{Na}-\mathrm{K}$ ATP ase complex was demonstrated by the method of MAYAHARA et al. (1980). The sections were incubated in a lead citrate medium containing $1.0 \mathrm{M}$ glycine- $\mathrm{KOH}$ buffer $(\mathrm{pH} 9.0), 4 \mathrm{mM}$ lead citrate $(\mathrm{K}$ and $\mathrm{K}$ Lab.), 25\% v/v DMSO, $0.1 \mathrm{M}$ p-nitrophenylphosphate (p-NPP, Mg salt, Sigma Chem. Co.), 2.5 $\mathrm{mM}$ Levamisole (Sigma Chem. Co.), final pH 8.8.

Table 1. Histochemical enzyme activities in the atrioventricular node and the working myocardium of control and diabetic rat hearts

\begin{tabular}{|c|c|c|c|c|}
\hline & \multicolumn{2}{|c|}{ AV node } & \multicolumn{2}{|c|}{ Working myocardium } \\
\hline & Control & Diabetic & Control & Diabetic \\
\hline 1) PAS & $2+$ & $4+$ & $1+$ & $2+$ \\
\hline 2) Glycogen phosphorylase & $4+$ & $4+$ & $2+$ & $2+$ \\
\hline 3) Phosphofructokinase & $3+$ & $2+$ & $2+$ & $1+$ \\
\hline 4) Pyruvate dehydrogenase & $2+$ & $1+$ & $2+$ & $1+$ \\
\hline 5) Succinate dehydrogenase & $2+$ & $1+$ & $3+$ & $2+$ \\
\hline 6) G-6-P dehydrogenase & $2+$ & $1+$ & \pm & \pm \\
\hline 7) Oil red 0 & \pm & \pm & \pm & \pm \\
\hline 8) Acetylcholinesterase & $4+$ & $4+$ & $1+$ & $1+$ \\
\hline 9) Na-K ATPase & $4+$ & $3+$ & $2+$ & $1+$ \\
\hline
\end{tabular}

$4+:$ very strong activity, $3+:$ strong activity, $2+:$ moderate activity, $1+:$ low activity, $\pm:$ slight activity 
These sections were incubated in the same conditions and mounted with glycerine jelly for light microscopy.

\section{RESULTS}

Ten diabetic and 10 normal rats were examined. The mean fasting blood glucose was $333 \pm 9 \mathrm{mg} / \mathrm{dl}$ (mean \pm S.E.) in diabetic rats and $127 \pm 5 \mathrm{mg} / \mathrm{dl}$ in control rats. Table 1 indicates the histochemical activities of various enzymes in the working myocardium and atrioventricular (AV) node of control and diabetic rats. The AV node was localized at the border between the interatrial and the interventricular septa and stained heavily for acetylcholinesterase (Fig. 1). The PAS positive reaction was increased in the AV node compared to the working myocardium in control rats. Both of these PAS positive reactions were strongly increased in diabetic rat hearts compared to control rats (Fig. 2). The activity of phosphofructokinase, the rate limiting enzyme in glycolysis, was reduced in both the working myocardium and AV node of diabetic rat hearts. Mitochondrial enzymes, Pyruvate dehydrogenase, and succinate dehydrogenase activities were also reduced in both tissues of the diabetic rat hearts. The activity of Glucose-6-phosphate dehydrogenase, a regulatory enzyme of the pentose-phosphate cycle, was higher in the AV node than in the working myocardium of control rats. This enzyme activity was reduced both in the AV node and the working myocardium of diabetic rat hearts compared to those of control rats (Fig. 3). The activity of Ouabainsensitive $\mathrm{K}^{+}$-NPPase activity was higher in the AV node than in the working myocardium of control rats. In diabetic rat hearts, this activity was markedly reduced in the myocardium and slightly reduced in the AV node (Fig. 4).

Fig. 2. The PAS positive reaction of the atrioventricular $(A V)$ node. A: control, B: diabetes. The PAS positive reaction was increased in the AV node compared to the working myocardium in control rats. Both of these PAS positive reactions were strongly increased in diabetic rat hearts compared to control rats. $\times 25$

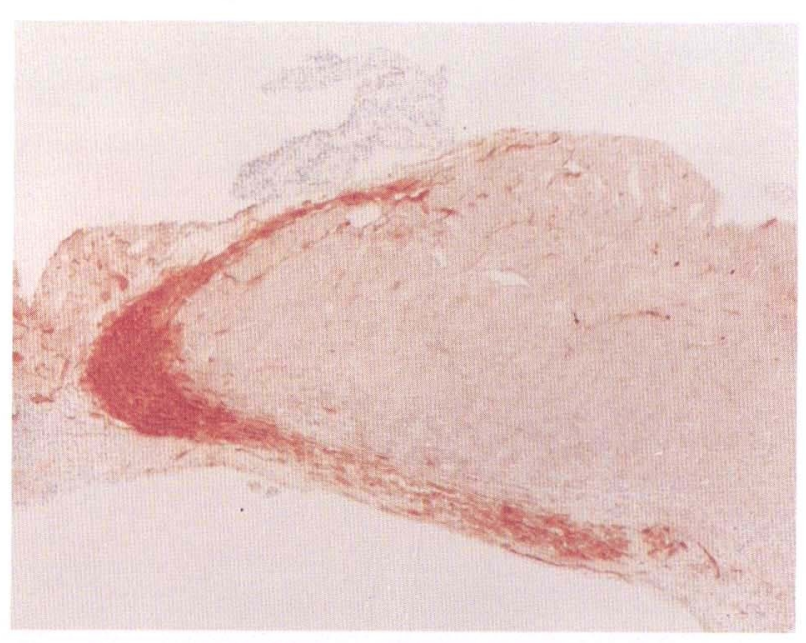

Fig. 1. Acetylcholine esterase staining of the atrioventricular node of the control rat heart. $\times 25$

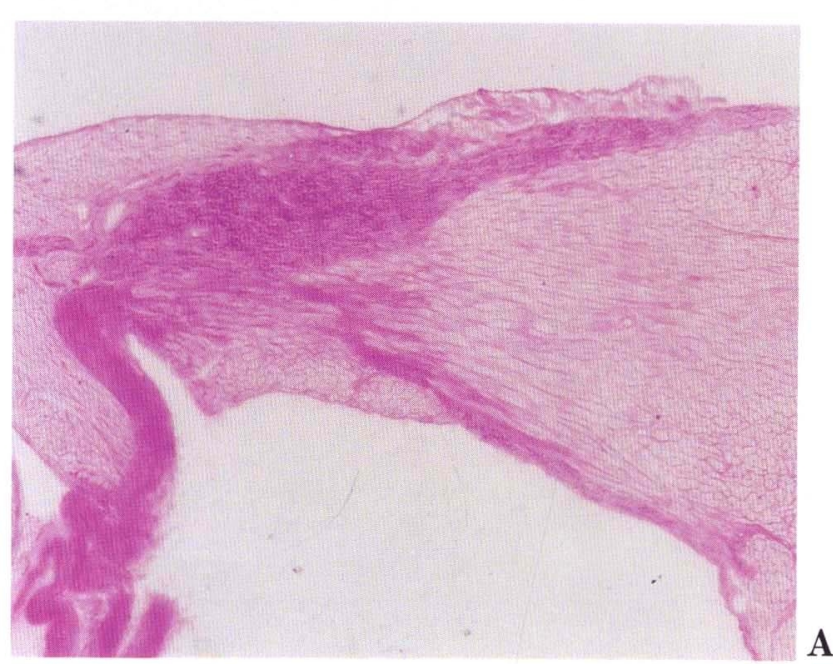

A

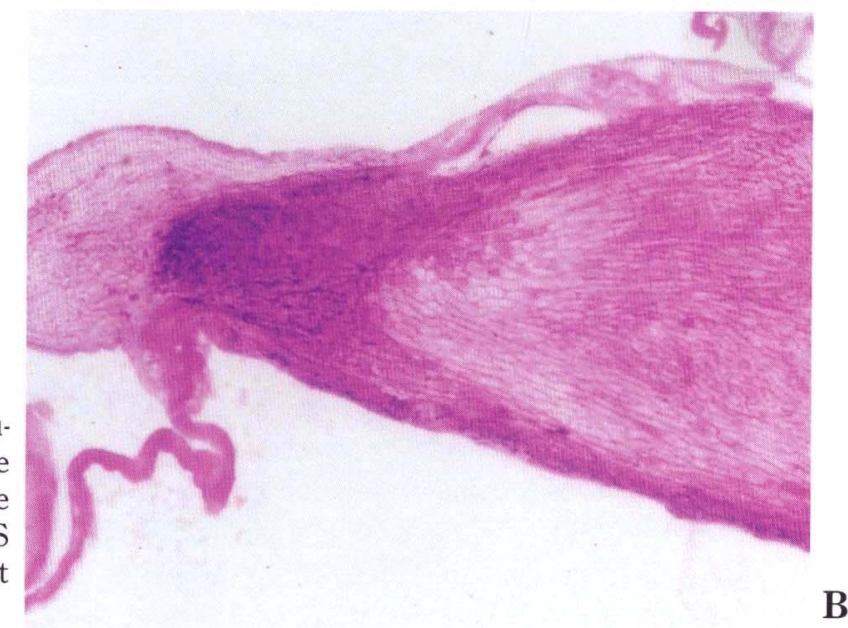



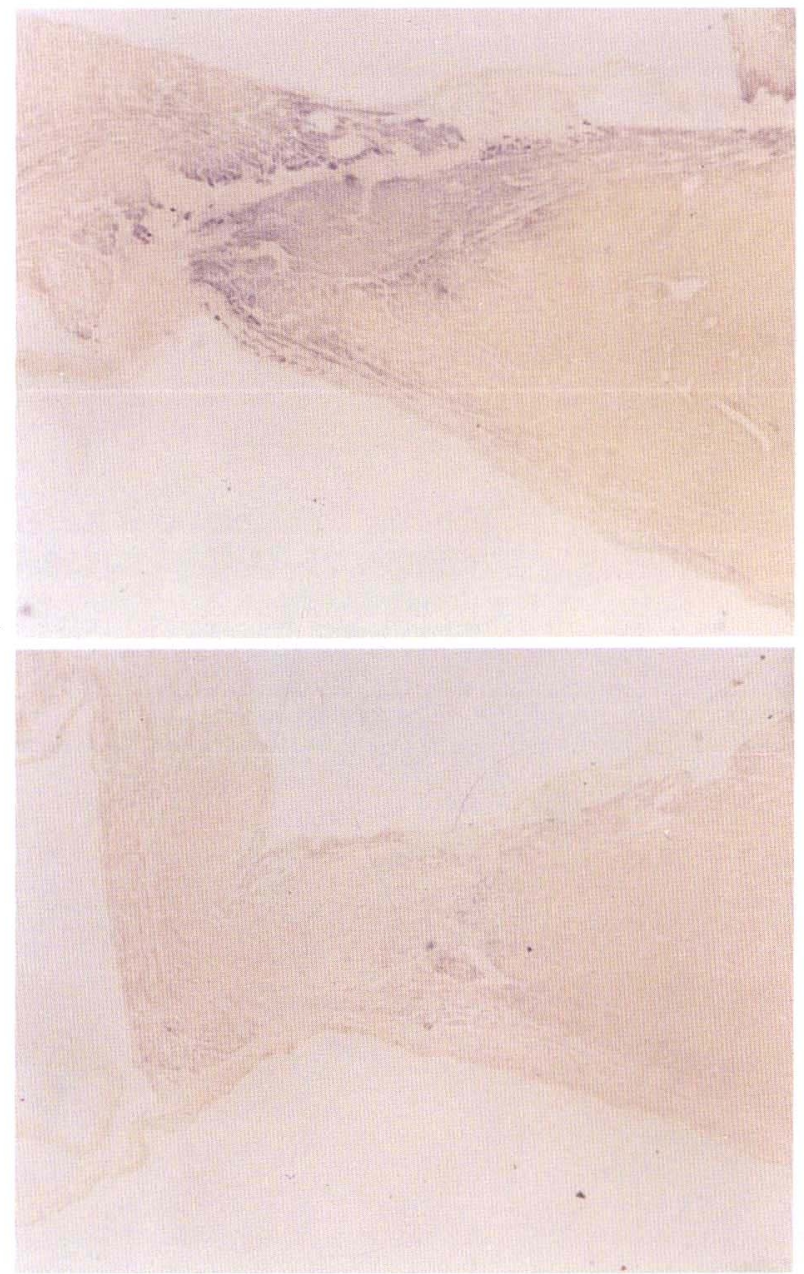

Fig. 3. The activity of Glucose-6-phosphate dehydrogenase of the atrioventricular $(A V)$ node. $\mathbf{A}$ : control, $\mathbf{B}$ : diabetes. This activity was higher in the AV node than in the working myocardium of control rats. This enzyme activity was reduced both in the AV node and the working myocardium of diabetic rat hearts compared to those of control rats. $\times 25$

\section{DISCUSSION}

The conduction system has been reported to have different metabolic properties compared to the working myocardium. Previous histochemical and biochemical studies of human and lower species have indicated that the oxygen uptake and the activity of succinate dehydrogenase were much lower in the conduction system whereas the glycogen concentra-

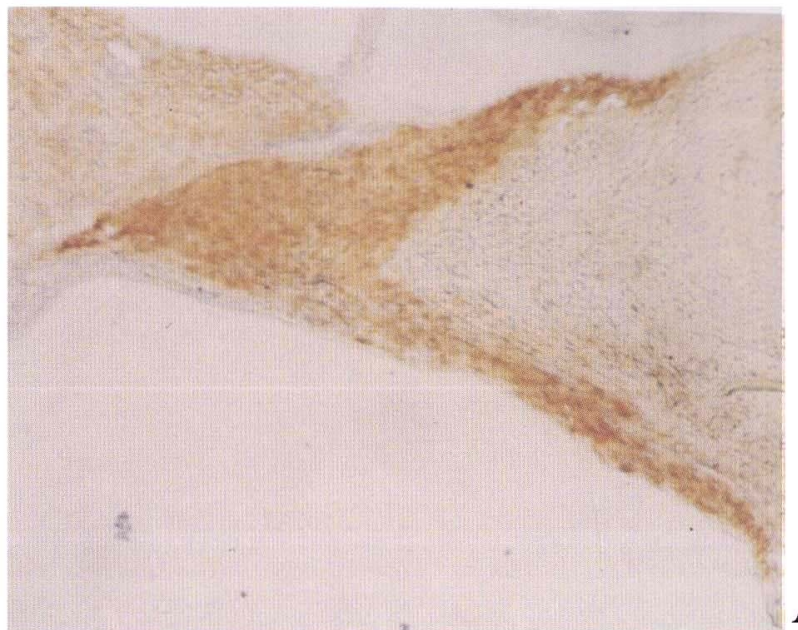

A

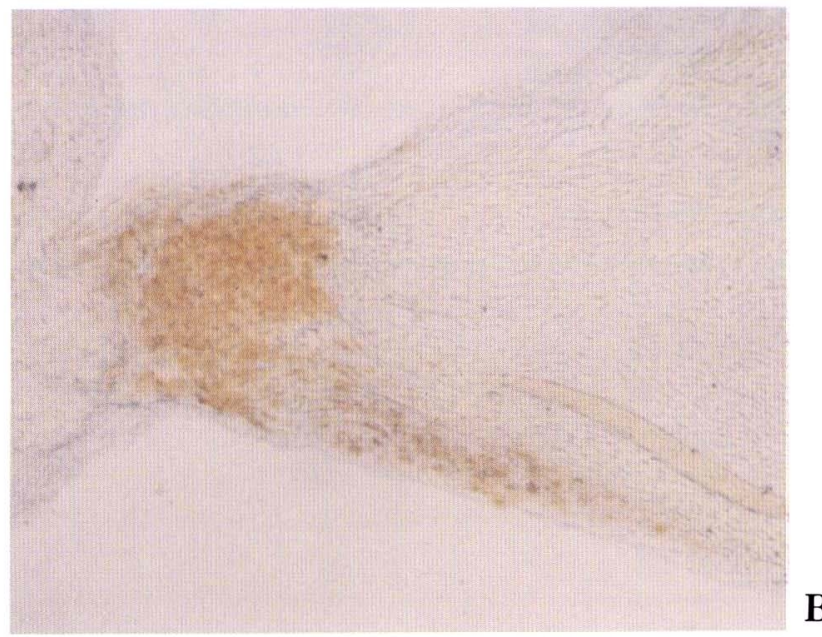

Fig. 4. The activity of ouabain-sensitive, $\mathrm{K}^{+}$-dependent p-nitrophenylphosphate $\left(\mathrm{K}^{+}\right.$-NPPase $)$of the atrioventricular (AV) node. A : control, B: diabetes. This activity was higher in the AV node than in the working myocardium of control rats. In diabetic rat hearts, this activity was markedly reduced in the myocardium and slightly reduced in the $\mathrm{AV}$ node. $\times 25$

tion was higher than in the working myocardium (SNIJder and MEIJER, 1970; MEIJER and DeVRIES, 1978; EliAs et al., 1980, 1982; TSUYUGuCHI et al., 1980; THÉRY et al., 1985). These data suggest that the conduction system may depend more on glycolysis for energy supply than does the working myocardium, and that it is more resistant to anoxic damages. Moreover, Glucose-6-phosphate dehydrogenase activity, the rate limiting enzyme of pentosephosphate pathway, is higher than that in the work- 
ing myocardium (SoGABE et al., 1987). This enzyme controls the generation of NADPH which requires the formation of reduced glutathione. The glutathione peroxidase enzymes using reduced glutathione as a co-factor are generally accepted as the main system for the protection of cells against lipid peroxidation. Therefore, the high level of glucose-6phosphate dehydrogenase activity is probably related to protection of the conduction system from peroxidative damage.

The alteration of the working myocardial metabolism in diabetic hearts has been extensively investigated by biochemical and enzyme histochemical methods. REAGAN et al. (1974) reported that Oil red O was positive in paravascular locations between cardiac cells of the diabetic dog heart induced by alloxan injection and kept for 11 months. However, we could not find any such differences between the control and diabetic rat hearts. Most of this discrepancy may be attributable to the duration of the diabetic condition and species differences.

TARACH (1978) found that the PAS positive reaction of the working myocardium was increased in alloxan diabetic rats. REAGAN et al. (1974) reported that the accumulation of PAS positive materials may be related to the altered myocardial stiffness of diabetic dogs. In our study, PAS positive reaction was markedly increased both in the conduction system and in the working myocardium, the conduction system being especially strongly positive in diabetic rat hearts. The activity of glycogen phosphorylase, a key enzyme of glycogenolysis, of the myocardium and the conduction system of diabetic hearts was the same as in the control hearts. However, the glycolytic enzyme, phosphofructokinase, was decreased. These changes indicate that more inhibition of glycolysis and more accumulation of glycogen exist in the conduction system of diabetic hearts. The decreased activity of glucose-6-phosphate dehydrogenase, a key enzyme of the pentose-phosphate cycle, in the conduction system of the diabetic heart suggest that it is also more susceptible to ischemic damages.

PIERCE and DHALla (1983) reported that sarcolemmal Na-K ATPase activity was decreased in diabetic rat hearts. In the present study, the activity of $\mathrm{K}^{+}$-NPPase of diabetic hearts was decreased both in the conduction system and in the working myocardium in comparison with control rats. Our results support their data. It is well known that the activity of Na-K ATPase effects the regulation of intracellular cation concentrations. The depression of $\mathrm{Na}-\mathrm{K}$ ATPase induces the elevation of intracellular sodium ( $₫ \mathrm{Na}\rfloor \mathrm{i})$, which in turn causes an increase in intracellular calcium ( $[\mathrm{Ca}] \mathrm{i})$ via the $\mathrm{Na}-\mathrm{Ca}$ exchange system. The elevation of the $[\mathrm{Ca}] \mathrm{i}$ of the myocardial cell is reported to have considerable extent in cell damage.

In conclusion, diabetic rat hearts have changes in metabolic conditions in the conduction system as well as in the working myocardium.

\section{REFERENCES}

Bonilla, E. and D. L. Schotland: Histochemical diagnosis of muscle phosphofructokinase deficiency. Arch. Neurol. 22: 8-12 (1970).

Elias, E. A., G. P. De Vries, R. A. Elias, A. J. Tigges and A. E. F. H. MeIJER: Enzyme histochemical studies on the conducting system of the human heart. Histochem. J. 12: 577-589 (1980).

Elias, E. A., R. A. Elias, G. P. De Vries and A. E. F. H. MeiJer: Early and late changes in the metabolic pattern of the working myocardial fibres and Purkinje fibres of the human heart under ischaemic and inflammatory conditions: an enzyme histochemical study. Histochem. J. 14: 445-459 (1982).

Ferguson, M. M.: Histochemical demonstration of pyruvate oxidase and $\alpha$-ketoglutarate oxidase. Histochemie 6: 185-186 (1966).

Ganda, O. P., A. A. Rossini and A. A. Like: Studies on streptozotocin diabetes. Diabetes 25: 595-603 (1976).

KARNovsky, M. J.: The localization of cholineterase activity in rat cardiac muscle by electron microscopy. J. Cell Biol. 23: 217-232 (1964).

Mayahara, H., K. Fujimoto, T. Ando and K. Ogawa: A new one-step method for the cytochemical localization of ouabain-sensitive, potassium-dependent p-nitrophenylphosphatase activity. Histochemistry 67: 125-138 (1980).

McDaniel, H. G., R. L. Jenkins, S. B. Digerness and L. O. RICHARD: Myocardial fuel and energy balance, acute ischemia and diabetes. Amer. J. Med. Sci. 295(3): 207-211 (1988).

Meijer, A. F. F. H. and G. P. De Vries: Enzyme histochemical studies in the Purkinje fibres of the atrioventricular system of the bovine and porcine hearts. Histochem. J. 10: 399-408 (1978).

Nachlas, M. M., K. Tsou, E. De Souza, C. Cheng and A. M. Seligman: Cytochemical demonstration of succinic dehydrogenase by the use of a new p-nitrophenyl substituted ditetrazole. J. Histochem. Cytochem. 5: 420436 (1957).

Pearse, A. G. E.: Histochemistry: theoretical and applied. 3rd ed. J. \& A. Churchill, London, 1968.

Pierce, G. N. and N. S. Dhalla: Sarcolemmal $\mathrm{Na}^{+} \cdot \mathrm{K}^{+}$. ATPase activity in diabetic rat heart. Amer. J. Physiol. 245: C241-247 (1983). 
Reagan, T. J., P. O. Ettinger, M. I. Khan, M. U. Jesrani, M. M. Lyons, H. A. Oldewurtel and M. WEBER: Altered myocardial function and metabolism in chronic diabetes mellitus without ischemia in dogs. Circul. Res. 35: 222-237 (1974).

RUdolPh, G. and H. J. KLEIN: Histochemische Darstellung und Verteilung der Glukose-6-PhosphatDehydrogenase in normalen Rattenorganen. Histochemie 4: 238-251 (1964).

SniJder, J. and A. E. F. H. Meijer: Enzyme histochemical studies on the Purkinje fibres of canine, bovine and porcrine hearts. Histochem. J. 2: 395-409 (1970).

Sogabe, T., M. MoRI and K. AKI: Biochemichal characterization of conduction system of the bovine heart. Jap. Heart J. 28: 85-95 (1987).

Taegtmeyer, H. and J. M. Passmore: Defective energy metabolism of the heart in diabetes. Lancet 1: 139-140 (1985).

TaKeUChI, T.: Histochemical differentiation of phosphorylase a, phosphorylase $\mathrm{b}$ and phosphorylase-kinase. J. Histochem. Cytochem. 10: 688 (1962).

TAKeUChI, T. and H. KURIAKI: Histochemical detection of phosphorylase in animal tissue. J. Histochem. Cytochem. 3: 153-160 (1955).

TARACH, J. S.: Some histochemical observations on the myocardial metabolism in experimental conditions. Acta Histochem. 61: 257-272 (1978).
Théry, C., I. Krivosic, P. Asseman and A. E. F. H. MeiJer: An enzyme histochemical study of human sinus node, coronary sinus, and mitral valve muscle. Circulation 72: 205-213 (1985).

Tsuyuguchi, N., K. Matsumura, Y. Tamura, T. Niki, H. MoRI and K. AKI: Biochemical studies on energy metabolism in the conduction system of bovine heart. Jap. Heart J. 21: 729-736 (1980).

Dr. Atsushi KuRoda

The First Department of Internal Medicine Kagoshima University School of Medicine Ushuki-1208, Kagoshima

890 Japan

黒田 篤

890 鹿児島市宇宿 1208-1

鹿児島大学医学部

第一内科学教室 